Article

\title{
IgE-Induced Mast Cell Activation Is Suppressed by Dihydromyricetin through the Inhibition of NF- $k B$ Signaling Pathway
}

\author{
Tsong-Min Chang ${ }^{1}$, Tzu-Chih Hsiao ${ }^{2}$, Ting-Ya Yang ${ }^{3}$ and Huey-Chun Huang ${ }^{3, *(D)}$ \\ 1 Department of Applied Cosmetology, Hungkuang University, Taichung 433304, Taiwan; ctm@hk.edu.tw \\ 2 Juwenlee Cosmetics Technology Center, LUO LI-FEN Group, Zhangzhou 363105, China; \\ atropa@ms18.hinet.net \\ 3 Department of Medical Laboratory Science and Biotechnology, College of Medicine, \\ China Medical University, Taichung 404333, Taiwan; tyyang@mail.cmu.edu.tw \\ * Correspondence: lchuang@mail.cmu.edu.tw; Tel.: +886-4-22053366 (ext. 7207)
}

check for

updates

Citation: Chang, T.-M.; Hsiao, T.-C.; Yang, T.-Y.; Huang, H.-C. IgE-Induced Mast Cell Activation Is Suppressed by Dihydromyricetin through the Inhibition of NF- $\kappa$ B Signaling Pathway. Molecules 2021, 26, 3877. https://doi.org/10.3390/ molecules 26133877

Academic Editors: Silvie Rimpelová and Raffaele Capasso

Received: 22 April 2021

Accepted: 22 June 2021

Published: 25 June 2021

Publisher's Note: MDPI stays neutral with regard to jurisdictional claims in published maps and institutional affiliations.

Copyright: (c) 2021 by the authors. Licensee MDPI, Basel, Switzerland. This article is an open access article distributed under the terms and conditions of the Creative Commons Attribution (CC BY) license (https:// creativecommons.org/licenses/by/ $4.0 /)$.

\begin{abstract}
Mast cells play a crucial role in the pathogenesis of type 1 allergic reactions by binding to $\mathrm{IgE}$ and allergen complexes and initiating the degranulation process, releasing pro-inflammatory mediators. Recently, research has focused on finding a stable and effective anti-allergy compound to prevent or treat anaphylaxis. Dihydromyricetin (DHM) is a flavonoid compound with several pharmacological properties, including free radical scavenging, antithrombotic, anticancer, and antiinflammatory activities. In this study, we investigated the anti-allergic inflammatory effects and the underlying molecular mechanism of DHM in the DNP-IgE-sensitized human mast cell line, KU812. The cytokine levels and mast cell degranulation assays were determined by enzyme-linked immunosorbent assay (ELISA). The possible mechanism of the DHM-mediated anti-allergic signaling pathway was analyzed by western blotting. It was found that treatment with DHM suppressed the levels of inflammatory cytokines TNF- $\alpha$ and IL-6 in DNP-IgE-sensitized KU812 cells. The anti-allergic inflammatory properties of DHM were mediated by inhibition of NF-kB activation. In addition, DHM suppressed the phosphorylation of signal transducer and activator of transcription 5 (STAT5) and mast cell-derived tryptase production. Our study shows that DHM could mitigate mast cell activation in allergic diseases.
\end{abstract}

Keywords: dihydromyricetin; mast cells; NF-kB; tryptase; STAT5

\section{Introduction}

The leaves of Ampelopsis grossedentata are a type of caffeine-free tea that is widely used to promote health. This plant is rich in polyphenols and flavonoids, and its main compound is ampelopsin, also called dihydromyricetin (DHM). DHM is a bioactive flavonoid compound that exhibits many pharmacological effects, such as anti-inflammatory, hepatoprotective, anti-carcinogenic, antioxidative, and anti-melanogenesis properties [1-4]. Previous studies have shown that flavonoids reduce allergic reactions [5]. Due to its beneficial activity, DHM has been extensively studied for structural identification, content determination, and pharmacological effects [1]. To date, little has been reported regarding the precise molecular targets by which DHM regulates human mast cell function. Importantly, it has been reported that naturally occurring polyphenoloic antioxidants, such as rutin and chlorogenic acid, could modulate IgE-mediated mast cell activation [6]. The polyphenolic structure of DHM and its antioxidant activity led to our investigation of its effect on IgE-mediated mast cell activation. However, little has been reported regarding the precise molecular mechanism by which DHM inhibits human mast cell function. 
There is emerging evidence that mast cells (MCs) play a central role in viral infections, systemic allergies, asthma, neuro-inflammatory diseases, and several stress disorders [7,8]. Mast cells activated in an allergen- and immunoglobulin E (IgE)-dependent manner subsequently trigger acute inflammatory reactions and promote chronic allergy progression by secreting histamine, proteases, and chemotactic factors, and engage in de novo synthesis of inflammatory cytokines. However, extensive mast cell activation leads to increased levels of inflammatory cytokines and chemokine release, which further exacerbates inflammation and increases disease severity [9]. In humans, two subsets of mast cells have been identified and characterized according to their expression of tryptase or chymase within cytoplasmic granules. The tryptase- and chymase-positive mast cell (MCTC) subtype encompasses the skin mast cells that express both tryptase and chymase, whereas the tryptase-positive mast cell (MCT) subpopulation only expresses tryptase and is predominately located in the lungs [8]. The NF- $\mathrm{KB}$ signaling cascade is responsible for the pro-inflammatory cytokines, TNF- $\alpha$ and IL-6, in activated mast cells. Triggered signaling of the Ras-Raf-Map kinase (MAPK) cascade consequently leads to the activation of a number of transcription factors required for the biological function of MCs. Moreover, signal transducers and activators of transcription 5 (STAT5) are critical for mast cell development, which increases the transcription of pro-inflammatory cytokines $[10,11]$. The critical contribution of STAT5 to mast cell biology was identified as the regulation of IgE-induced degranulation of mast cells [10,12]. In this study, the potential anti-allergic effects of DHM on IgE-mediated mast cell activation were investigated. We sensitized mast cells with dinitrophenol (DNP) IgE and then used DNP-human serum albumin antigen stimulation to activate the sensitized mast cells in vitro. The molecular mechanisms underlying the effects of DHM on IgE-mediated activation were also explored using human KU812 mast cells.

\section{Results}

\subsection{Effect of DHM on the Proliferation of KU812 Cells}

To determine the concentrations of DHM in our study, we sensitized KU812 cells with $100 \mathrm{ng} / \mathrm{mL}$ DNP-IgE for $16 \mathrm{~h}$ and stimulated with DNP-HSA for $4 \mathrm{~h}$. Trypan blue assay data showed significant hyperproliferation compared to non-sensitized mast cells. The dosage effect of DHM on KU812 cells was evaluated by treatment with $10 \mu \mathrm{M}$ and $100 \mu \mathrm{M}$ DHM for $24 \mathrm{~h}$; as observed, $100 \mu \mathrm{M}$ DHM could more effectively inhibit IgE-induced mast cell proliferation. Treatment with $100 \mu \mathrm{M}$ DHM for $24 \mathrm{~h}$ had no significant cytotoxic effect on KU812 cells (Figure 1).

\subsection{Inhibitory Effects of DHM on the Generation of Oxidative Stress}

Intracellular oxidative stress was evaluated by treating KU812 cells with DHM followed by DNP-IgE challenge. The cellular reactive oxygen species (ROS) levels were measured by flow cytometry and were dramatically right shifted in the DNP-IgE-treated cells, whereas the ROS levels were reduced in cells treated with $100 \mu \mathrm{M}$ DHM. These results demonstrate that DHM can effectively scavenge ROS and reduce the oxidative stress induced by DNP-IgE in mast cells (Figure 2).

\subsection{DHM Decreases DNP-IgE-Upregulated Pro-Inflammatory Cytokines and Inhibits Ige-Dependent Activation of the MAPK and NF- $\kappa B$ Signaling Pathways in KU812 Cells}

KU812 cells were sensitized with DNP-IgE for $16 \mathrm{~h}$ followed by DNP-HSA stimulation for $4 \mathrm{~h}$ prior to DHM treatment. IgE activation results in the release of pro-inflammatory mediators, leading to the exacerbation of allergic responses. We investigated whether DHM treatments were able to modulate the release of the pro-inflammatory cytokines TNF- $\alpha$ and IL-6. DHM treatment significantly reduced the IgE-induced upregulation of TNF- $\alpha$, in a dose-dependent manner (Figure 3A). DHM treatment significantly inhibited IL-6 cytokine levels (Figure 3B). 


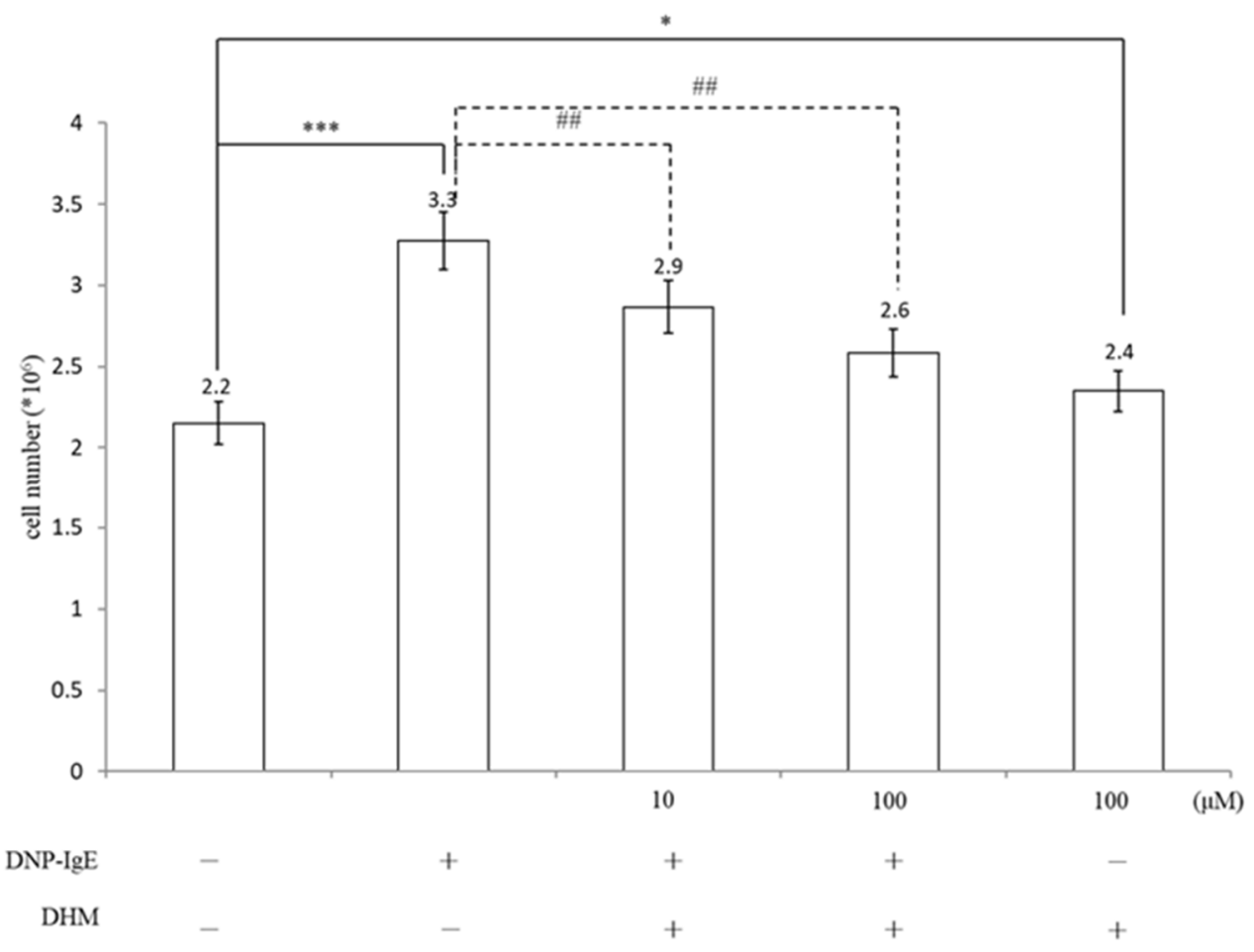

Figure 1. Effect of DHM on the proliferation of KU812 cells. Cell proliferation was assessed by trypan blue assay. Results show the fold relative to the control. Data represent the mean \pm SD of three independent experiments. ${ }^{*} p<0.05,{ }^{* * *} p<0.001$ as compared with untreated control and \#\# $p<0.01$ as compared with DNP-IgE.

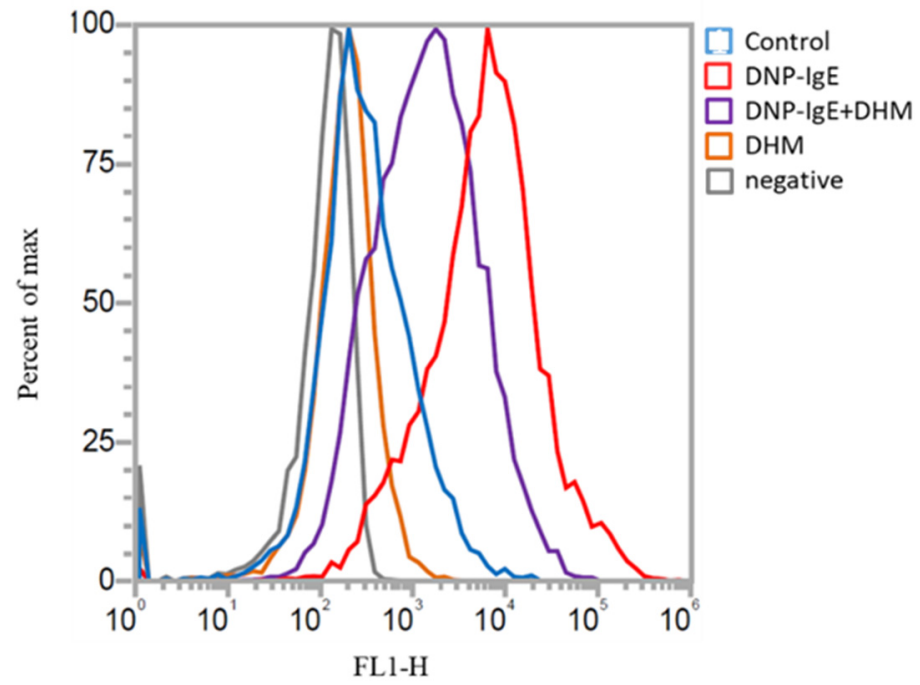

Figure 2. DHM $(100 \mu \mathrm{M})$ alleviates the oxidative levels in IgE-activated KU812 cells. Representative flow cytometry profiles show changes in the levels of ROS in IgE-challenged KU812 cells after treatment with DHM. A histogram of fluorescence channel (FL1-H) versus cell count (y-axis) was generated to show cells stained with DCFH-DA in comparison to the non-sensitized control cells. Three independent, representative experiments are presented.

As the activation of MAPK and NF- $\mathrm{KB}$ is essential for the transcriptional regulation of allergic responses, we further investigated whether the inhibition of allergic responses by DHM is mediated through the NF- $\mathrm{BB}$ pathway in KU812 cells. IgE-induced activation of NF-KB was reduced by DHM treatment (Figure $3 \mathrm{C}$ ). It has been reported that the activation of NF- $\mathrm{KB}$ is triggered by mitogen-activated protein kinases (MAPKs), including extracellular signal-regulated kinase (ERK), c-Jun NH2-terminal kinase (JNK), and p38 
MAPK. As shown in Figure 3C, DHM suppressed the IgE-induced activation of p38 MAPK, but did not affect the phosphorylation of ERK or JNK.

\subsection{DHM Promotes Recovery from IgE-Induced Degranulation}

Upon activation, mast cells release a myriad of preformed factors, and the levels of tryptase were determined in KU812 supernatants. IgE challenge induced a significant increase in tryptase activity. The addition of $100 \mu \mathrm{M}$ DHM reduced the IgE-induced release of tryptase $(1.75 \pm 0.1 \mu \mathrm{g} / \mathrm{mL})$ to $(1.13 \pm 0.211 \mu \mathrm{g} / \mathrm{mL})$, which was nearly $64.5 \%$ of the value of the DNP-IgE group (Figure 4). These findings indicate that DHM attenuates IgE-induced mast cell degranulation.

\subsection{DHM Inhibited IgE-Mediated Mast Cell Activation through Suppression of STAT5 Signaling Pathway}

Hyperactivated STAT5 leads to the aberrant expression of pro-inflammatory genes, which promote hypersensitivity $[13,14]$. The STAT signaling pathways can "cross-talk" with the MAPK pathway and the NF-KB pathway [15]. To reveal the exact molecular targets of DHM, we examined the effects of DHM on the phosphorylation of STAT5 kinases, which are the most upstream kinases responsible for mast cell activation. DHM treatment suppressed the phosphorylation levels of STAT5 in activated KU812 cells. Pimozide is an FDA-approved cell-permeable drug with STAT5-inhibitory activity [16,17]. Treatment with pimozide decreased STAT5 phosphorylation. The combination of pimozide and DHM further exaggerated the reduction in DNP-IgE-induced phosphor-STAT5. DHM synergizes with pimozide in suppressing STAT5 signaling in KU812 cells (Figure 5).

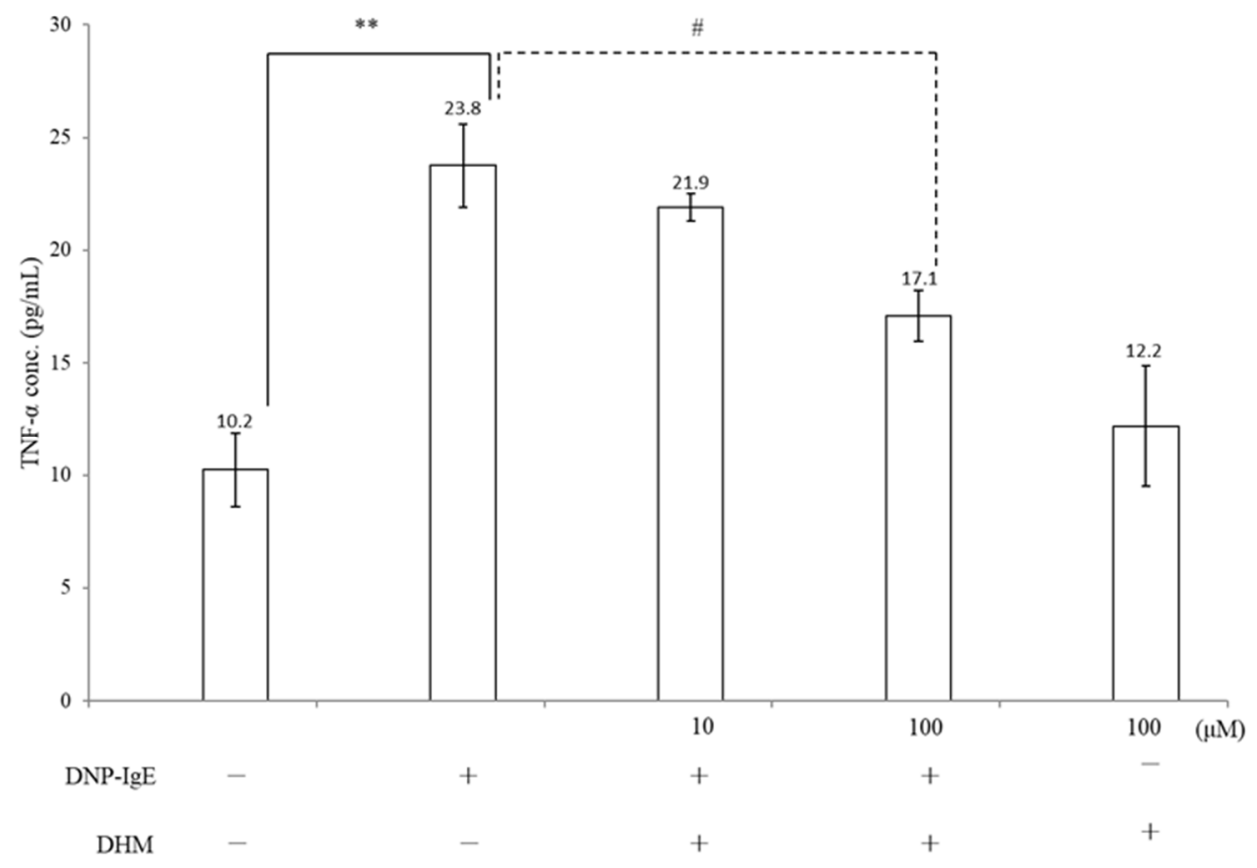

(A)

Figure 3. Cont. 


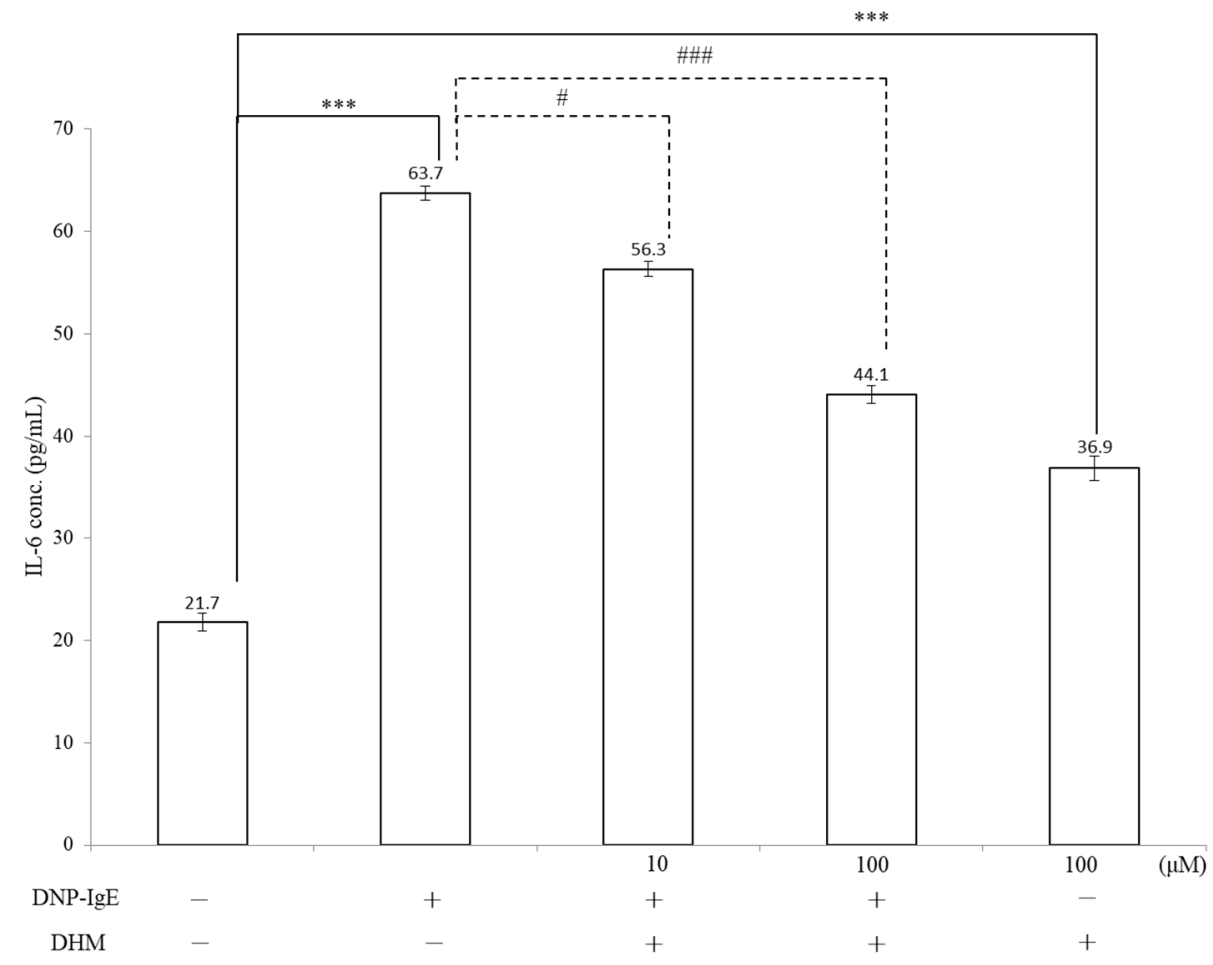

(B)

\begin{tabular}{|c|c|c|c|c|c|}
\hline DNP-IgE & - & + & + & + & - \\
\hline \multirow[t]{2}{*}{ DHM } & - & - & + & + & + \\
\hline & & & 10 & 100 & 100 \\
\hline
\end{tabular}

pERK

ERK

$\mathrm{pJNK}$

JNK

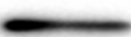

pP38
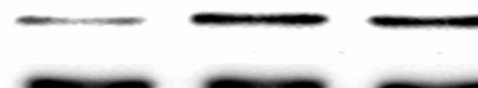

p65
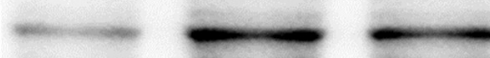

GAPDH

(C)

Figure 3. Cont. 


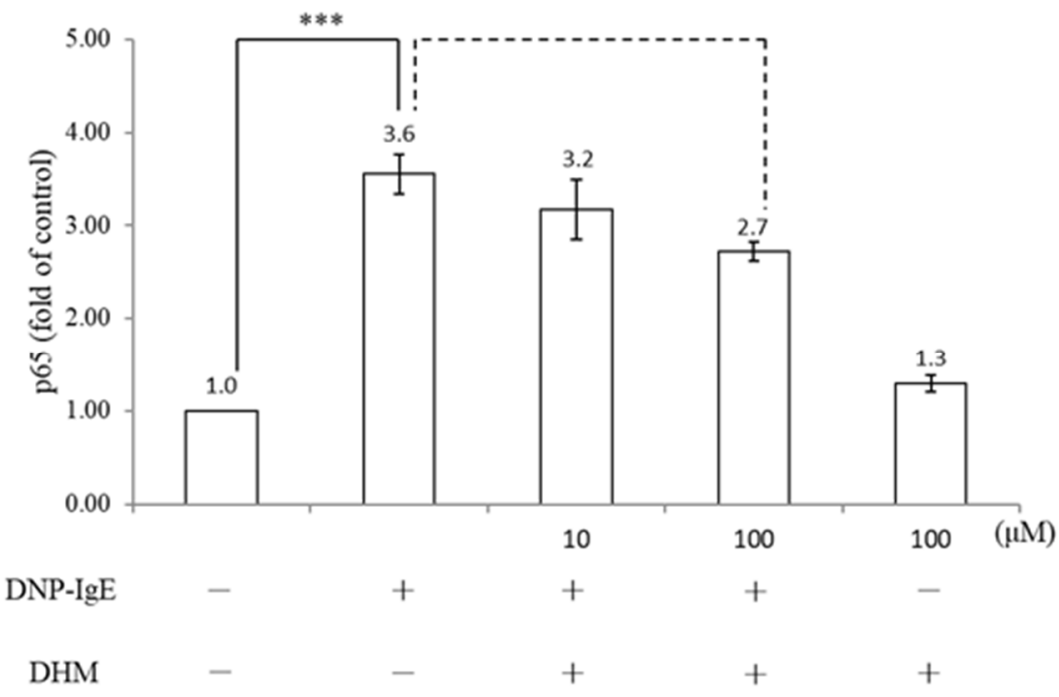

(D)

Figure 3. The effect of DHM on cytokine production and signaling pathway. Incubation with DHM led to decreased production of TNF- $\alpha$ (A) and IL-6 (B) after sensitization with DNP-IgE. All bars depict the mean of 3 repeated experiments with SD. ${ }^{* *} p<0.01,{ }^{* * *} p<0.001$ as compared with the untreated control and \# $p<0.05$, \#\#\# $p<0.001$ as compared with DNP-IgE. Levels of total and phosphorylated MAPKs (C) and the expression of NF-KB (D) were assessed by western blot.

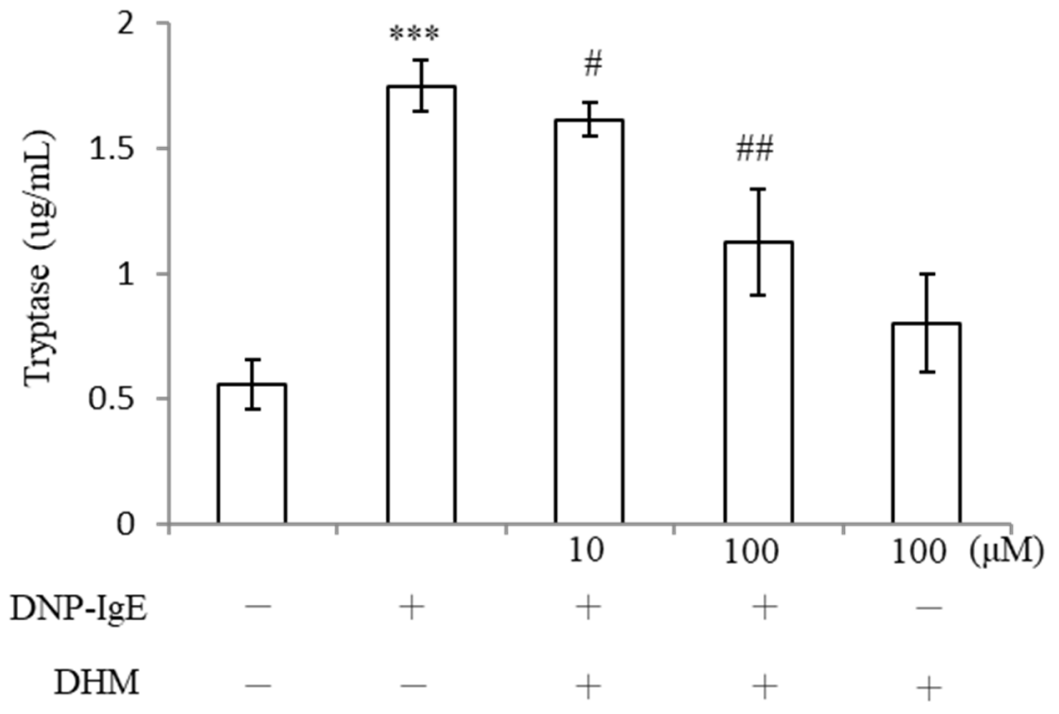

Figure 4. DHM reduced degranulation from KU812 cells after IgE-DNP-induced activation. KU812 cells were either sensitized with DNP-IgE or treated with DHM. The amount of tryptase from a million cells released into the supernatants was quantified using a degranulation kit after $24 \mathrm{~h}$ of incubation. Data represent the mean \pm SD of three independent experiments. ${ }^{* * *} p<0.001$ as compared with untreated control and \#p<0.05, \#\# $p<0.01$ as compared with DNP-IgE. 


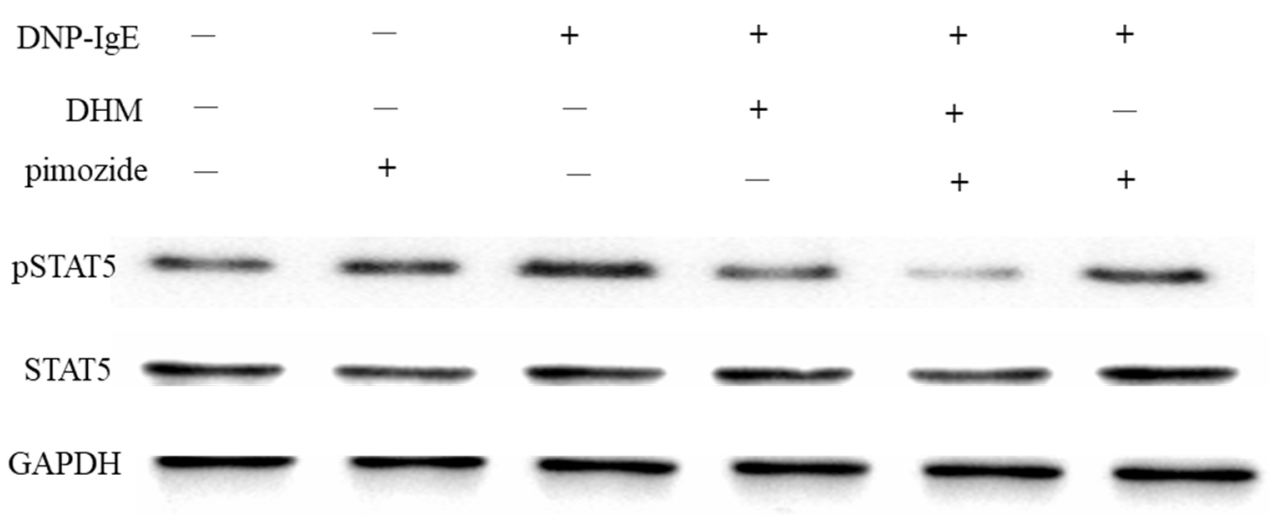

(A)

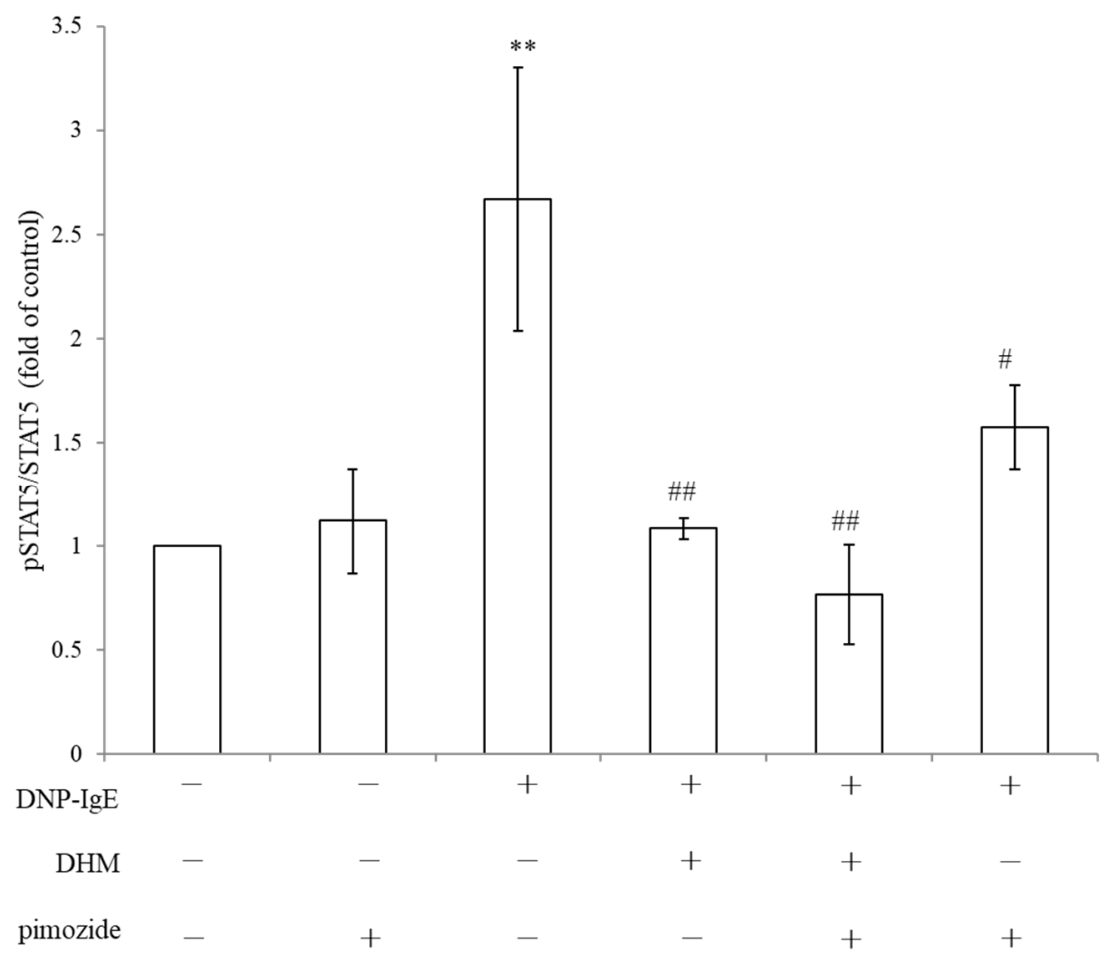

(B)

Figure 5. DHM inhibits the IgE-inducing STAT5 pathways in KU812 cells. Representative western blots of p-STAT5 (A). Protein expression in KU812 cells, cells treated with DNP-IgE, $10 \mu \mathrm{M}$ pimozide, $100 \mu \mathrm{M}$ DHM, or both compounds combined. Pimozide in combination with DHM suppressed the expression of p-STAT5 compared with either compound alone. The relative ratio of phosphorylated protein to total protein levels were presented as the mean $\pm \mathrm{SD}$ (B). Fold of control, ${ }^{* *} p<0.01$, \# Fold of DNP IgE, \# $p<0.05$, \#\# $p<0.01$.

We observed a decreased phosphorylation of NF- $\mathrm{kB}$ and STAT, according to western blot analysis. Thus, DHM may inactivate the degranulation and cytokine production in IgE-activated KU812 cells through the suppression of the NF- $\mathrm{KB}$ and STAT pathways (Figure 6). 


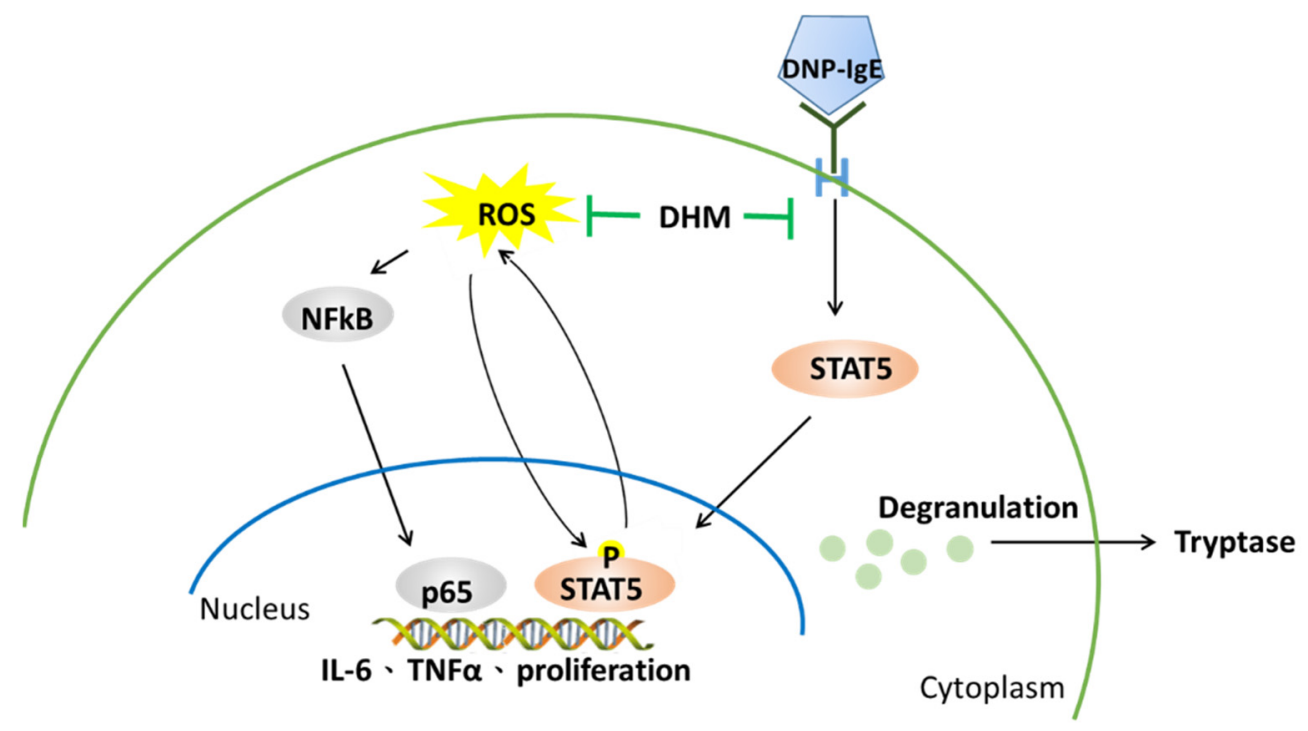

Figure 6. Proposed mechanism by which DHM diminishes IgE-stimulated cell proliferation, cytokine production, and degranulation in KU812 cells.

\section{Discussion}

In the present study, DHM was investigated for its ability to suppress IgE-mediated responses in cultured human mast cells. Published records have shown the anti-inflammatory properties of DHM, evidenced by the effective protection of human umbilical vein endothelial cells (HUVECs) damaged by fatty acids [18], DHM can also inhibit intracellular lipid accumulation in human acute monocytic leukemia cells (THP-1 cells) [19] and suppress the activation of the NF- $\mathrm{kB}$ signaling pathways and downstream pro-inflammatory cytokines in HeLa cells [13]. Our work further demonstrated that DHM counteracts the DNP-IgE-induced mediator release through its antioxidant and anti-inflammation activities in KU812 cells.

Mast cells are long-lived tissue-resident immune cells that migrate to and differentiate within tissues. In healthy tissues, mast cells are maintained in constant numbers, while the mast cell population increases dramatically in chronically allergic tissues [14]. In principle, increased mast cell numbers could be a driving mechanism in many disorders. The employed DHM did not show any cytotoxicity in KU812 cells, suggesting that these concentrations are within safety limits. DHM was found to inhibit IgE-triggered mast cell proliferation.

Previous research has demonstrated that mast cells play a crucial role in the mediation of allergic reactions via the degranulation process, predominantly caused by the antigen$\operatorname{IgE}$ antibody reaction [20]. The degree of degranulation reflects mast cell activation. Tryptase is a mast cell protease that is expressed by all mast cells and contributes to inflammation in the skin and several autoimmune diseases by causing smooth muscle contraction and fibrosis [21]. The results of the present study showed that DHM has the ability to suppress the degranulation of mast cells and can be considered a pharmacological target for addressing mast cell mediator-related symptoms.

However, our study identified STAT5, but not ERKs, as involved in the mechanism integrating DHM anti-inflammation activity. IgE crosslinked with cognate receptors activates the subsequent Jak-Stat pathway in mast cells. Activated STATs bind to specific DNA sequences and initiate transcription of target genes [22]. STAT5 has been recognized in these signaling cascades that control mast cell function and expansion of the mast cell population $[23,24]$. The exacerbated inflammation caused by IgE was offset by the pSTAT5 inhibitor pimozide following DHM. The results of this study revealed that DHM significantly attenuated IgE-induced ROS and suppressed STAT5 phosphorylation, which could be one of the important mechanisms underlying the protective effect of DHM on abnormal mast cell proliferation and mastocytosis. 
ROS-mediated oxidation of upstream kinases can influence the NF- $k B$, which modulates cytokine expression in innate immunity [25]. In addition, ROS also modulate STAT activation in normal and cancer cells, and in turn, STAT5 modulates ROS production, ultimately leading to the feed-forward loop that augments STAT5 activation and drives ROS formation [26,27]. These results suggest that NF- $\mathrm{kB}$ and ROS-mediated signaling is important in IgE-mediated mast cell activation. Our study also demonstrated that DHM mitigated the mast cell activity could help manage allergic disorders.

\section{Materials and Methods}

The cell line identified as an immature human basophilic leukocyte KU812 cell line [11] was purchased from the Bioresource Collection and Research Center, Taiwan. Dinitrophenyl-bovine serum albumin (DNP-HSA), anti-dinitrophenyl IgE isotype (DNP$\mathrm{IgE})$, dihydromyrecitin, and pimozide were purchased from Sigma-Aldrich Chemical Co. (Merck KGaA, Darmstadt, Germany). ELISA kits for cytokine assays were purchased from eBioscience (San Diego, CA, USA). Primary antibodies against GAPDH were purchased from Santa Cruz Biotechnology Inc. (Dallas, TX, USA). Primary antibodies against phospho-I $\mathrm{B} \alpha, \mathrm{I} \kappa \mathrm{B} \alpha, \mathrm{NF}-\kappa \mathrm{B}$ p65, phospho-STAT5a and STAT5 were purchased from Cell Signaling Technology, Inc. (Danvers, MA, USA). The chemical reagents used in this study were purchased from the Sigma-Aldrich Chemical Co.

\subsection{Cell Proliferation Assay}

KU812 cells were grown in a RPMI-1640 medium containing 10\% heat-inactivated fetal calf serum and $1 \%$ antibiotics under standard cell culture conditions $\left(37^{\circ} \mathrm{C}, 5 \% \mathrm{CO}_{2}\right.$ in a humidified incubator). Cell viability was determined by measuring cell number. Briefly, KU812 cells were sensitized with DNP-IgE $(100 \mathrm{ng} / \mathrm{mL})$ for $16 \mathrm{~h}$, stimulated with DNPHSA antigens $(100 \mathrm{ng} / \mathrm{mL})$ for $4 \mathrm{~h}$, and further treated with HSA DHM for $24 \mathrm{~h}$ at $37^{\circ} \mathrm{C}$. The cell numbers were counted using a hemocytometer with trypan blue staining [28].

\subsection{Cytokines Measurement}

Supernatants obtained from cell cultures in the various treatment groups were analyzed for interleukin IL-6 and tumor necrosis factor (TNF)- $\alpha$ using an enzyme-linked immunosorbent assay (ELISA) kit, according to the manufacturer's instructions.

\subsection{Reactive Oxygen Species (ROS) Measurement Using a Flow Cytometer}

Flow cytometer is an useful approach to study the ROS contents in cells receiving different stimuli [29]. KU812 cells were seeded in 96-well plates at a concentration of $1 \times 10^{5}$ cells $/ \mathrm{mL}$. Cells sensitized with DNP-IgE $(100 \mathrm{ng} / \mathrm{mL})$ for $16 \mathrm{~h}$ were incubated with DNP-HSA $(100 \mathrm{ng} / \mathrm{mL})$ for $4 \mathrm{~h}$ at $37^{\circ} \mathrm{C}$. The prepared cells were subsequently incubated with DHM for $24 \mathrm{~h}$. After treatment with $10 \mu \mathrm{M}$ 2, 7-dichlorofluorescein diacetate (DCFHDA; Sigma-Aldrich, Darmstadt, Germany)) in PBS for 30 min, cells were subjected to flow cytometry (Attune NxT, Thermo Fisher Scientific, Waltham, MA, USA) analysis to examine the amount of ROS within cells.

\subsection{Western Blot Analysis}

Cells were lysed in PBS containing 1\% nonidet P-40, $0.5 \%$ sodium deoxycholate, $0.1 \%$ sodium dodecyl sulfate (SDS), $5 \mu \mathrm{g} / \mathrm{mL}$ aprotinin, $100 \mu \mathrm{g} / \mathrm{mL}$ phenylmethylsulfonyl fluoride, $1 \mu \mathrm{g} / \mathrm{mL}$ pepstatin A, and $1 \mathrm{mM}$ ethylenediaminetetraacetic acid (EDTA) at $4{ }^{\circ} \mathrm{C}$ for $20 \mathrm{~min}$. Total lysates were quantified using a microBCA kit (Thermo Fisher Scientific, Waltham, MA, USA). Proteins ( $10 \mu \mathrm{g}$ ) were resolved by SDS-polyacrylamide gel electrophoresis and electrophoretically transferred to a polyvinylidene fluoride membrane. The membrane was blocked in 5\% fat-free milk in PBST (PBS with $0.05 \%$ Tween-20), followed by overnight incubation with the following primary antibodies diluted in PBST: p65 Ab (1:1000) and pSTAT5a Ab (1:1000). The primary antibodies were removed and the membranes were washed extensively in PBST. Subsequent incubation with horseradish 
peroxidase-conjugated secondary antibodies (1:20,000, Santa Cruz Biotech, Dallas, TX, USA) was performed at room temperature for $2 \mathrm{~h}$. The membrane was again extensively washed in PBST to remove any excess secondary antibodies, and the blots were visualized using enhanced chemiluminescence reagent (GE Healthcare, South Jakarta, Indonesia).

\subsection{Mast Cell Degranulation Assay}

A mast cell degranulation assay kit (IMM001, Millipore, MA, USA) was used to determine tryptase concentration. KU812 cells $\left(1 \times 10^{6}\right.$ cells $\left./ \mathrm{mL}\right)$ were sensitized with DNP-IgE $(100 \mathrm{ng} / \mathrm{mL})$ for $16 \mathrm{~h}$. After washing twice with PBS, the cells were stimulated with DNP-HSA $(100 \mathrm{ng} / \mathrm{mL}$ ) for an additional $4 \mathrm{~h}$. To measure tryptase release (a biomarker of degranulation) from cells, supernatants and cell lysates were incubated in a substrate solution $\left(1.3 \mathrm{mg} / \mathrm{mL}\right.$ of tosyl-gly-pro-lys-pNA in $0.1 \mathrm{M}$ sodium carbonate) at $37^{\circ} \mathrm{C}$ for $1 \mathrm{~h}$, and the reaction was terminated by adding a stop solution ( $50 \mathrm{mM}$ sodium carbonate) for $15 \mathrm{~min}$ at room temperature. Absorption was measured at $405 \mathrm{~nm}$, and the results were expressed as the percentage of tryptase released.

\subsection{Statistical Analysis}

All data are presented as the mean \pm standard deviation (SD) from three, four, or six independent experiments, as indicated. For analysis of two groups, statistical analysis was conducted using Student's $t$-test (sigma plot 10.0. Systat Software, Inc., San Jose, CA, USA). Statistical significance was defined as $p<0.05$, and indicated by asterisks as follows: ${ }^{*} p<0.05,{ }^{* *} p<0.01,{ }^{* * *} p<0.001$.

\section{Conclusions}

The inhibition of allergic mediator generation by mast cells is an important therapeutic strategy in the context of allergic inflammatory diseases. In the present study, we provide evidence that DHM could be developed as a mast cell stabilizer in disease therapy by suppressing IgE-dependent tryptase release, as observed by targeting STAT5 kinases, which are the upstream signaling molecules for mast cell degranulation. Moreover, DHM reduced pro-inflammatory cytokine production in a dose-dependent manner in DNP-IgEsensitized KU812 cells by suppressing the STAT5 and NF- $\mathrm{kB}$ signaling pathways.

Author Contributions: Conceptualization, T.-M.C. and H.-C.H.; methodology: T.-Y.Y.; software: T.-Y.Y.; validation: T.-M.C., T.-Y.Y. and T.-C.H.; formal analysis, T.-Y.Y.; investigation, T.-M.C., T.Y.Y. and T.-C.H.; resources, T.-C.H.; data curation, T.-Y.Y.; writing-original draft preparation, H.C.H.; writing-review and editing, T.-M.C.; visualization, T.-Y.Y.; supervision, H.-C.H.; project administration, T.-M.C. and H.-C.H.; funding acquisition, T.-M.C. and H.-C.H. All authors have read and agreed to the published version of the manuscript.

Funding: This research was funded by the Ministry of Science and Technology (grant numbers MOST-108-2314-B-039-050-, MOST-109-2637-B-241-002-, and MOST-110-2622-8-241-001-TE4). The study was also financially supported by China Medical University, Taiwan under grant number CMU-108-Z-01.

Acknowledgments: The authors acknowledge the experiments and data analysis performed in part through the use of the Medical Research Core Facilities Office of Research \& Development at China Medical University, Taichung, Taiwan. The authors also acknowledge the financial support provided by the Higher Education Sprout project funded by the Ministry of Education (MOE) in Taiwan.

Conflicts of Interest: The authors declare no conflict of interest.

Sample Availability: Samples of the compounds are available from the authors. 


\section{References}

1. Zhang, J.; Chen, Y.; Luo, H.; Sun, L.; Xu, M.; Yu, J.; Zhou, Q.; Meng, G.; Yang, S. Recent Update on the Pharmacological Effects and Mechanisms of Dihydromyricetin. Front Pharm. 2018, 9, 1204. [CrossRef]

2. Chen, S.; Zhao, X.; Wan, J.; Ran, L.; Qin, Y.; Wang, X.; Gao, Y.; Shu, F.; Zhang, Y.; Liu, P.; et al. Dihydromyricetin improves glucose and lipid metabolism and exerts anti-inflammatory effects in nonalcoholic fatty liver disease: A randomized controlled trial. Pharmacol. Res. 2015, 99, 74-81. [CrossRef]

3. Chen, T.; Zhu, S.; Lu, Y.; Cao, H.; Zhao, Y.; Jiang, G.; Zhu, L.; Lu, T. Probing the interaction of anti-cancer agent dihydromyricetin with human serum albumin: A typical method study. Anti-Cancer Agents Med. Chem. 2012, 12, 919-928. [CrossRef]

4. Huang, H.-C.; Liao, C.-C.; Peng, C.-C.; Lim, J.-M.; Siao, J.-H.; Wei, C.-M.; Chen, C.-C.; Wu, C.-S.; Chang, T.-M. Dihydromyricetin from Ampelopsis grossedentata inhibits melanogenesis through down-regulation of MAPK, PKA and PKC signaling pathways. Chem. Biol. Interact. 2016, 258, 166-174. [CrossRef] [PubMed]

5. Kawai, M.; Hirano, T.; Higa, S.; Arimitsu, J.; Maruta, M.; Kuwahara, Y.; Ohkawara, T.; Hagihara, K.; Yamadori, T.; Shima, Y.; et al. Flavonoids and Related Compounds as Anti-Allergic Substances. Allergol. Int. 2007, 56, 113-123. [CrossRef] [PubMed]

6. Chen, S.; Gong, J.; Liu, F.; Mohammed, U. Naturally occurring polyphenolic antioxidants modulate IgE-mediated mast cell activation. Immunology 2000, 100, 471-480. [CrossRef] [PubMed]

7. Galli, S.J.; Tsai, M. IgE and mast cells in allergic disease. Nat. Med. 2012, 18, 693-704. [CrossRef] [PubMed]

8. Krystel-Whittemore, M.; Dileepan, K.N.; Wood, J.G. Mast Cell: A Multi-Functional Master Cell. Front. Immunol. 2016, 6, 620. [CrossRef] [PubMed]

9. Kempuraj, D.; Selvakumar, G.P.; Ahmed, M.E.; Raikwar, S.P.; Thangavel, R.; Khan, A.; Zaheer, S.A.; Iyer, S.S.; Burton, C.; James, D.; et al. COVID-19, Mast Cells, Cytokine Storm, Psychological Stress, and Neuroinflammation. Neuroscientist 2020, 26, $402-414$. [CrossRef]

10. Barnstein, B.O.; Li, G.; Wang, Z.; Kennedy, S.; Chalfant, C.; Nakajima, H.; Bunting, K.D.; Ryan, J.J. Stat5 Expression Is Required for IgE-Mediated Mast Cell Function. J. Immunol. 2006, 177, 3421-3426. [CrossRef] [PubMed]

11. Shelburne, C.P.; McCoy, M.E.; Piekorz, R.; Sexl, V.; Roh, K.-H.; Jacobs-Helber, S.M.; Gillespie, S.R.; Bailey, D.P.; Mirmonsef, P.; Mann, M.N.; et al. Stat5 expression is critical for mast cell development and survival. Blood 2003, 102, 1290-1297. [CrossRef] [PubMed]

12. Pullen, N.; Falanga, Y.; Morales, J.; Ryan, J. The Fyn-STAT5 Pathway: A New Frontier in IgE- and IgG-Mediated Mast Cell Signaling. Front. Immunol. 2012, 3, 17. [CrossRef]

13. Tang, N.; Ma, J.; Wang, K.S.; Mi, C.; Lv, Y.; Piao, L.X.; Xu, G.H.; Li, X.; Lee, J.J.; Jin, X. Dihydromyricetin suppresses TNF- $\alpha$-induced NF-KB activation and target gene expression. Mol. Cell. Biochem. 2016, 422, 11-20. [CrossRef]

14. Crimi, E.; Chiaramondia, M.; Milanese, M.; Rossi, G.A.; Brusasco, V. Increased numbers of mast cells in bronchial mucosa after the late-phase asthmatic response to allergen. Am. Rev. Respir. Dis. 1991, 144, 1282-1286. [CrossRef]

15. Grivennikov, S.I.; Karin, M. Dangerous liaisons: STAT3 and NF-kappaB collaboration and crosstalk in cancer. Cytokine Growth Factor Rev. 2010, 21, 11-19. [CrossRef] [PubMed]

16. Kabata, H.; Moro, K.; Fukunaga, K.; Suzuki, Y.; Miyata, J.; Masaki, K.; Koyasu, S.; Betsuyaku, T.; Asano, K. Pimozide, A C33 CYTOKINES AND ASTHMA MEDIATORS: Pimozide, A Stat5 Inhibitor, Counteracts Corticosteroid-Resistant Airway Inflammation Induced By Il-33 And Tslp. Am. J. Respir. Crit. Care Med. 2014, 189, 1.

17. Rondanin, R.; Simoni, D.; Maccesi, M.; Romagnoli, R.; Grimaudo, S.; Pipitone, R.M.; Meli, M.; Cascio, A.; Tolomeo, M. Effects of Pimozide Derivatives on pSTAT5 in K562 Cells. ChemMedChem 2017, 12, 1183-1190. [CrossRef]

18. Hu, Q.; Zhang, T.; Yi, L.; Zhou, X.; Mi, M. Dihydromyricetin inhibits NLRP3 inflammasome-dependent pyroptosis by activating the Nrf2 signaling pathway in vascular endothelial cells. Biofactors 2018, 44, 123-136. [CrossRef]

19. Zeng, Y.; Peng, Y.; Tang, K.; Wang, Y.Q.; Zhao, Z.Y.; Wei, X.Y.; Xu, X.L. Dihydromyricetin ameliorates foam cell formation via LXR $\alpha$-ABCA1/ABCG1-dependent cholesterol efflux in macrophages. Biomed. Pharmacother. 2018, 101, 543-552. [CrossRef]

20. Manikandan, J.; Kothandaraman, N.; Hande, M.P.; Pushparaj, P.N. Deciphering the structure and function of FceRI/mast cell axis in the regulation of allergy and anaphylaxis: A functional genomics paradigm. Cell. Mol. Life Sci. Cmls 2012, 69, 1917-1929. [CrossRef] [PubMed]

21. Siebenhaar, F.; Redegeld, F.A.; Bischoff, S.C.; Gibbs, B.F.; Maurer, M. Mast Cells as Drivers of Disease and Therapeutic Targets. Trends Immunol. 2018, 39, 151-162. [CrossRef]

22. Sun, S.-C.; Maggirwar, S.B.; Harhaj, E.W.; Uhlik, M. Binding of c-Rel to STAT5 target sequences in HTLV-I-transformed T cells. Oncogene 1999, 18, 1401-1409. [CrossRef]

23. Morales, J.K.; Falanga, Y.T.; Depcrynski, A.; Fernando, J.; Ryan, J.J. Mast cell homeostasis and the JAK-STAT pathway. Genes Immun. 2010, 11, 599-608. [CrossRef] [PubMed]

24. Ando, T.; Xiao, W.; Gao, P.; Namiranian, S.; Matsumoto, K.; Tomimori, Y.; Hong, H.; Yamashita, H.; Kimura, M.; Kashiwakura, J.-I.; et al. Critical role for mast cell Stat5 activity in skin inflammation. Cell Rep. 2014, 6, 366-376. [CrossRef]

25. Lingappan, K. NF-kB in Oxidative Stress. Curr. Opin. Toxicol. 2018, 7, 81-86. [CrossRef] [PubMed]

26. Bourgeais, J.; Gouilleux-Gruart, V.; Gouilleux, F. Oxidative metabolism in cancer: A STAT affair? Jak-Stat 2013, 2, e25764. [CrossRef]

27. Mi, T.; Wang, Z.; Bunting, K.D. The Cooperative Relationship between STAT5 and Reactive Oxygen Species in Leukemia: Mechanism and Therapeutic Potential. Cancers 2018, 10, 359. [CrossRef] [PubMed] 
28. Strober, W. Trypan Blue Exclusion Test of Cell Viability. Curr. Protoc. Immunol. 2015, 111, A3.B.1-A3.B.3. [CrossRef] [PubMed]

29. Cossarizza, A.; Ferraresi, R.; Troiano, L.; Roat, E.; Gibellini, L.; Bertoncelli, L.; Nasi, M.; Pinti, M. Simultaneous analysis of reactive oxygen species and reduced glutathione content in living cells by polychromatic flow cytometry. Nat. Protoc. 2009, 4, 1790-1797. [CrossRef] 